\title{
Analisis Kendala Penggunaan Bahasa Dalam Pekerjaan Pada Masyarakat Sunda
}

\author{
Gusti Leony Augustya Prathiwi \\ Institut Komunikasi dan Bisnis LSPR, Jakarta, Indonesia
}

\begin{abstract}
ABSTRAK
Indonesia adalah negara kepulauan yang memiliki beragam kebudayaan dan juga bahasa. Adanya keanekaragamanan budaya ini dapat saling bersinggungan saat bertemu. Demikian juga dengan adanya sebuah perusahaan pembiayaan non-bank yang memiliki cabang tersebar di seluruh Indonesia. Hal ini mengakibatkan terjadinya permutasiaan karyawan yang berbeda budaya untuk beradaptasi di lingkungan kerja yang baru. Salah satunya bisa juga dengan lingkungan suku Sunda. Orang non-Sunda memasuki lingkungan Sunda yang mayoritas menggunakan bahasa daerah Sunda sebagai bahasa seharihari menemukan kesulitan. Kesulitan ini menjadi penghambat dalam berkomunikasi. Hambatan tersebut salah satunya adalah bahasa yang berbeda. Penelitian ini dilakukan untuk mengetahui dan menganalisis hambatan bahasa bagi karyawan non-Sunda di lingkungan kerja Sunda dan juga bagaimana cara mereka beradaptasi untuk dapat berkomunikasi. Selain budaya organisasi dan juga strategi individu menjadi perhatian dalam penelitian ini. Metode yang digunakan yaitu studi kasus. Dengan nara sumber dua orang Sunda dan dua orang non Sunda sebagai sumber data penelitian. Hal ini menjadi menarik dibahas karena penyesuaian dilakukan oleh individu pada saat menghadapi kegiatan dalam jangka waktu lama, dalam hal ini bekerja.
\end{abstract}

Kata kunci: Bahasa; Sunda; kendala lingkungan kerja; komunikasi organisasi

\begin{abstract}
Indonesia is an archipelago that has a lot of differences in languages and cultures. This kind of diversity of culture could make a conflict. Same as one of non-bank company in Indonesia that has many branches all over Indonesia. This company has a regulation for their employee to work on the new environment with different culture. One of them is Sundanese culture. People that is non-Sundanese get in Sundanese environment that is usual to used Sundanese language as their daily conversation and communication. This could make the new comers difficult to understand. This kind of difficulty could make a miscommunication happen. The one of the factors is language. paper tells about what kind of problem that could be face by non- Sundanese employee in Sundanese environment. How they could adapt to communicate. Their individual strategies and also the organization culture would be focus in this paper. The interviewees come from two Sundanese and two non-Sundanese as an employee. This is one of interesting topic because communication in working place is one of intensive communication.
\end{abstract}

Keywords: language; Sundanese; problems in working place; organization communication 


\section{PENDAHULUAN}

Bahasa adalah alat komunikasi antar manusia. Untuk mengungkapkan pesan yang ingin disampaikan secara langsung maupun tidak langsung (kiasan). Penggunaan bahasa penting adanya dalam proses komunikasi agar tidak terjadi kesalahpahaman. Kehidupan manusia tanpa adanya bahasa akan terbatas. Adapun bahasa yang digunakan adalah bahasa lisan maupun tulisan. Menurut Mulyana dan Rakhmat (2005, p. 30) "bahasa merupakan alat bagi orangorang untuk berinteraksi dengan orang-orang lain dan juga sebagai alat untuk berpikir, maka, bahasa berfungsi sebagai suatu mekanisme untuk berkomunikasi dan sekaligus sebagai pedoman untuk melihat realitas sosial".

Berdasarkan definisi tersebut, bahasa adalah penggunaan secara lisan ataupun bentuk lainnya bagi manusia untuk berkomunikasi satu sama lain. Dimana di dalam bahasa, tidak hanya terjadi pertukaran informasi tetapi juga adanya makna yang diungkapkan. Persoalan bahasa adalah hal yang menarik untuk dibahas. Dimana adanya perbedaan bahasa dapat mengakibatkan penerimaan pesan yang berbeda atau bahkan salah.

Pengalaman penulis dalam mengalami kendala untuk memahami bahasa yang berbeda membuat penulis tertarik untuk meneliti perbedaan bahasa ini. Penulis menggunakan bahasa yang berbeda untuk keperluan yang berbeda ataupun dengan orang yang berbeda. Bahasa yang sering digunakan adalah bahasa daerah dan bahasa Indonesia. Mengapa kesenjangana ini bisa terjadi?

Dikatakan oleh Chaer (2007) bahwa bahasa bersifat unik dan mempunyai hubungan yang sangat erat dengan budaya masyarakat pemakainya. Seperti contohnya dalam bahasa Jawa yaitu terdapat tingkatan penggunaan bahasa. Perbedaan ini dilihat dari penggunaannya terhadap lawan bicara. Apabila lawan bicara adalah orang yang dituakan atau dihormati maka akan digunakan bahasa dengan tingkatan yang paling sopan, atau disebut "kromo". Dilanjutkan pula dengan penggunaan bagi lawan bicara yang seumur atau lebih akrab atau lebih muda. Perbedaan bahasa seperti ini penting untuk dipahami. Dikarenakan bila terjadi salah penggunaan akan menimbulkan efek dari lawan bicara, seperti merasa tidak dihormati atau dianggap kesenjangan tidak mengetahui budaya. Oleh karena itu, penggunaan bahasa adalah hal yang penting dalam kehidupan sehari-hari.

Indonesia yang memiliki banyak pulau ini tidak mendapatkan kesamarataan dalam hal ekonomi, pendidikan, dan kesejahteraan. Dikarenakan adanya keterbatasan wilayah yang diakibatkan oleh pembatas dari laut, gunung, hutan, dan lain sebagainya. Jakarta, sebagai Ibukota negara Indonesia, merupakan salah satu kota yang paling banyak mendapatkan pengaruh dan perkembangannya. Dilanjutkan dengan kota-kota lain yang berada di satu pulau dengan Jakarta, seperti Bandung, Jogja, dan Surabaya. Hal ini tentunya mengakibatkan adanya perpindahan penduduk dari tempat terpencil menuju tempat yang memiliki perkembangan lebih baik. Oleh karena itu, dewasa ini banyak terjadi mutasi orang ke satu tempat ke tempat lain. 
Demikian juga dalam dunia pekerjaan, dengan banyaknya perusahaan milik perorangan maupun milik negara yang membuka cabang di luar Jakarta memberikan peluang bagi orang yang ingin bekerja dan ingin kehidupannya berkembang, tidak perlu lagi berpindah tempat. Hal ini memungkinkan adanya pemerataan dalam hal ekonomi, pendidikan dan lain sebagainya.

Perpindahan ini mengakibatkan adanya interaksi dan juga penyesuaian bagi orang yang berpindah tempat. Misalkan saja sebuah perusahaan membuka cabang baru, maka perlu adanya kaderisasi yang dibantu oleh orang pusat (misalkan Jakarta) untuk berbagi ilmu dan melakukan pelatihan bagi orang lokal (misalkan Bandung). Dengan adanya interkasi ini maka muncul pula hambatan dalam hal bahasa. Seperti yang telah dipaparkan sebelumnya bahwa Bangsa Indonesia lebih banyak menggunakan bahasa daerah dibandingkan Bahasa Indonesia sendiri. Hambatan dalam hal bahasa ini tidak hanya menjadikan kesulitan dalam berkomunikasi. Akan tetapi juga dalam hal budaya, kebiasaan, sopan santun, tingkah laku, gaya berbusana, sampai dengan kebiasaan cara bekerja.

Adanya beberapa perusahaan yang melakukan mutasi bagi karyawannya tentunya membutuhkan adaptasi tertentu bagi karyawan tersebut. Seperti yang telah disampaikan sebelumnya, bahwa masih banyak suku bangsa di Indonesia yang menggunakan bahasa daerah. Hal ini menimbulkan pertanyaan berapa lama waktu yang dibutuhkan untuk memberikan pelatihan bagi karyawan yang dimutasikan. Bagaimana cara karyawan baru diterima oleh suatu tempat, siapa yang perlu melakukan penyesuaian. Pemberlakuan mutasi ini biasa dilakukan oleh perusahaan untuk tingkat level supervisor. Sebagai bentuk upgrade ilmu bagi karyawan atau juga untuk menghindari adanya penguasaan terhadap pihak-pihak tertentu. Adapun alasan lain yang mungkin dijabarkan.

Berdasarkan latar belakang di atas, fokus penelitian ini adalah apa kendala penggunaan bahasa Sunda bagi orang non-Sunda dalam pekerjaan? dan bagaimana cara orang non-Sunda mengatasi kendala kesenjangan bahasa Sunda dalam pekerjaan? Adapun tujuan penelitian adalah memahami kendala bahasa Sunda bagi orang non-Sunda di lingkup pekerjaan dan mengungkap cara pekerja non-Sunda mengatasi kendala kesenjangan bahasa Sunda. Masalah yang akan dibahas dalam penelitian dibatasi pada penggunaan bahasa Sunda dalam lingkup kerja peneliti di sebuah perusahaan pembiayaan non-Bank yang berlokasi di Bandung bagi orang non-Sunda.

\section{Komunikasi Antar Budaya.}

Peneliti melakukan penelitian sehubungan dengan kendala penggunaan bahasa dalam pekerjaan di lingkungan pekerjaan berbahasa Sunda. Penelitian sebelumnya yang telah ada digunakan peneliti untuk menjadi referensi dalam penulisan penelitian ini. Adapun penelitian sebelumnya yang menjadi referensi adalah penelitian dalam hal topik yang serupa atau mendekati, dalam hal perbedaan bahasa ataupun budaya.

Ada beberapa penelitian sebelumnya yang membahas mengenai komunikasi antar budaya yang di dalamnya terdapat kendala dalam berbahasa. Contohnya penelitian mengenai adanya cultural barrier yang dihadapi oleh bisnis asing yang ingin masuk ke dalam bisnis negara 
Jepang (Billore \& Borg, 2014). Penelitian yang membahas mengenai kesulitan bisnis asing untuk melaukan penetrasi dalam pasar Jepang akibat perbedaan budaya. Penelitian lain yang juga memberikan referensi dalam hal komunikasi bangsa yang berbeda adalah penelitian mengenai adanya cultural barrier dalam pengaruhnya terhadap komunikasi dan tingkat stress karyawan di PT. Krakatau Daedong Machinery di Cilegon (Zahra \& Prasetya, 2016). Perbedaan budaya yang diangkat oleh tulisan tersebut adalah adanya perbedaan bahasa yang dapat menjadi hambatan dalam komunikasi antara karyawan asing dan karyawan lokal (Indonesia).

Kedua penelitian tersebut memberikan referensi dalam hal adanya culture barrier yang menjadi penghambat dalam proses komunikasi antar buadaya. Selain itu, kedua penelitian sebelumnya ini menyampaikan perlunya pemahaman bahasa diikuti pemahaman budaya tertentu perlu adanya dalam kelancaran komunikasi antara orang dengan dua budaya berbeda. Kajian teori yang digunakan dalam penelitian tersebut adalah model komunikasi dari Wilbur Schramm. Adanya elemen vital dalam model komunikasi tersebut antara lain adalah sumber pengolah pesan, penerima pesan, dan pesan yang dapat disampaikan secara verbal maupun non verbal. Adanya kemiripan pengalaman dari sumber pengolah pesan penting adanya untuk menyampaikan pesan kepada penerima pesan. Akan tetapi jika pengalaman atau referensi tidak sama maka akan muncul kesulitan komunikasi. Salah satu contoh ketidaksamaan referensi adalah bahasa. Penelitian ini juga menyampaikan pentingnya perbedaan budaya untuk diketahui agar tidak terjadi kesalahpahaman dalam memperlakukan individu atau kelompok lintas budaya. Pemahaman tersebut tidak dapat dilakukan secara instan tetapi membutuhkan waktu dan usaha. Perbedaan komunikasi yang perlu dipahami juga adalah komunikasi verbal dan non verbal.

Penelitian lain adalah milik Monika Teguh yang membahas perbedaan bahasa Korea dan Indonesia dari mahasiswa Korea di lingkungan Universitas Ciputra. Adanya sikap malu dan takut, ada kesulitan dalam komunikasi dalam hal ini bahasa yang menjadi penghambat. Ketiga penelitian sebelumnya tersebut dikategorikan sebagai komunikasi kelompok antar budaya karena merupakan proses komunikasi sejumlah orang, seperti kelompok non-Jepang yang akan memasuki pasar kelompok Jepang, kelompok karyawan asing dan karyawan Indonesia, serta kelompok mahasiswa Korea dengan mahasiswa Indonesia/dosen Indonesia. Komunikasi kelompok yang berbeda latar belakang budaya ini menunjukkan bahwa hambatan yang muncul dapat dicarikan solusinya.

Selain itu ada pula penelitian lain mengenai komunikasi antar etnis Jawa dan Tionghoa di lingkungan kerja antar karyawan (Kusuma \& Sutanto, 2015) yang menjelaskan adanya perbedaan bahasa dapat mengakibatkan kesalahan pahaman. Demikian pula dengan penelitian adanya komunikasi etnis Arab dan etnis Sunda di Cianjur melalui perkawinan Mut'ah atau perkawinan (Utami, 2016) menyatakan perlunya komunikasi dan pemahaman bahasa dalam berinteraksi saat terjadinya perkawinan mut'ah.

Kedua penelitian tersebut membahas adanya komunikasi antarpribadi dengan latar belakang kebudayaan yang berbeda, yaitu Jawa (Indonesia) dan Tionghoa serta Arab dan Sunda 
(Indonesia). Kedua pribadi ini berinteraksi dalam komunikasi karena memiliki tujuan. Proses komunikasi berbeda budaya ini menemukan hambatan dan berproses dalam penyelesaian guna mencapai tujuan. Selain itu juga membahas mengenai bahasa seperti yang akan diteliti oleh penulis. Bahasa sebagai alat komunikasi memiliki peran dalam bertukar informasi antar pribadi yang berbeda latar belakang budaya. Contoh penelitian terdahulu memberikan contoh adanya budaya dalam organisasi yang diciptakan dan diterapkan bagi karyawan guna mencapai kedisiplinan dan tujuan bersama. Selain itu, guna alat komunikasi dalam keberagaman yang terdapat di dalam sebuah organisasi. Pentingnya hal tersebut dapat menjadi referensi penelitian bagi penulis.

Penelitian ini membahas mengenai komunikasi di dalam lingkungan kerja, oleh karena itu komunikasi organisasi menjadi referensi penelitian ini. Contohnya tulisan yang membahasa budaya organisasi berbasis high dan low context dalam komunikasi bisnis beda budaya (Rozalena, 2014) menjelaskan adanya budaya yang diterapkan dalam organisasi, yaitu budaya Sunda dan nilai-nilai agama Islam. Penelitian ini akan menjadi bahan referensi dikarenakan adanya kesamaan topik pembahasan.

Wilbur Lang Schramm seorang tokoh dalam dunia komunikasi yang lahir di Marietta, Ohio, Amerika Serikat pada tanggal 5 Agustus 1907. Schramm mengambarkan proses komunikasinya melibatkan pengirim pesan, pesan, dan penerima pesan. Pengirim pesan atau komunikator mengirimkan pesan kepada penerima atau komunikan bergantung pada pengalaman dan kondisinya. Kemudian komunikan dapat memberikan feedback setelah menerima pesan dari komunikator. Dalam hal ini komunikan dapat menjadi komunikator. Demikian juga setelahnya komunikator berlaku sebagai komunikan. Bentuk timbal balik seperti ini dalam komunikasi memerlukan syarat adanya kesesuaian pengalaman yang sama. Adaya perbedaan dalam pengalaman ini menyebabkan komunikasi terhenti.

Penelitian ini menggunakan teori komunikasi dari Wilbur Schramm di mana perlu adanya kesamaan pengalaman dalam proses komunikasi. Salah satu kendala dalam berkomunikasi adalah perbedaan bahasa, dalam hal ini bahasa Sunda dan non-Sunda. Dalam pekerjaan perlu adanya komunikasi melalui bahasa agar aktivitas dapat berjalan sesuai dan lancar. Seperti disampaikan oleh Nuryanto (2011, p. 13) bahwa "syarat berjalannya proses komunikasi ini adanya kesesuaian terhadap pemahaman lapangan. Tanpa adanya pengalaman lapangan yang sama antara komunikator dan komunikan akan menyebabkan interpretasi yang berbeda terhadap suatu obyek/gagasan. Perbedaan ini menjadikan proses komunikasi berhenti dan tidak berlanjut”. Proses komunikasi melalui teori Schramm ini mengambarkan hubungan yang dinamis. Sumber pesan dan penerima pesan saling mempengaruhi, keduanya dapat berfungsi ganda sebagai penerima dan pengirim.

Selain itu, komunikasi antarbudaya (KAB) juga digunakan dalam pembahasan ini, KAB adalah bentuk komunikasi yang terdiri dari komunikator dan komunikan yang memiliki latar belakang budaya berbeda. Perbedaan tersebut perlu disadari oleh kedua belah pihak. Perbedaan itu dapat berupa nilai, bahasa, sikap dan bentuk lainnya. Perbedaan ini perlu dipahami dan disesuaikan agar tidak menimbulakn kesalahpahaman, “...kita perlu memahami situasi dan kondisi di mana 
proses komunikasi antar budaya itu beroperasi. ...In what and what context, contact, interaction, or communication" (Liliweri, 2002, p.21).

Komunikasi yang digunakan dalam penelitian ini adalah komunikasi organisasi. Adanya jalur komunikasi vertikal, horizontal, dan diagonal. Dalam organisasi adanya perbedaan latar belakang pendidikan, budaya, pengetahuan, dan lainnya mudah sekali ditemui. Maka dari itu dunia pekerjaan di dalamnya termasuk adanya komunikasi organisasi.

Dalam pekerjaan adanya komunikasi vertikal antar atasan dan bawahan akan lebih sering terjadi. Hal ini disebabkan dalam lingkungan pekerjaan peneliti setiap dua tahun sekali mungkin kurang akan terjadi mutasi untuk golongan leader. Oleh karena itu, kendala dalam perbedaan budaya akan sering terjadi. Demikian pula dengan jalur komunikasi horizontal adanya hubungan komunikasi dengan rekan sejawat. Bentuk budaya yang berbeda latar belakang ini cukup berpengaruh dalam dunia kerja. Adanya permintaan dan penerimaan instruksi kerja yang bisa terjadi kesalahpahaman. Oleh karena itu, perlu adanya adaptasi yang baik dan keterbukaan antar pengirim dan penerima pesan.

Komunikasi antar budaya dalam penelitian berikut melibatkan penulis dan juga koresponden dalam kendala di pekerjaan. Sebagaimana diketahui masyarakat Sunda masih menggunakan bahasa Sunda sebagai bahasa sehari-hari, termasuk dalam dunia pekerjaan. Keberadaan bahasa Indonesia sebagai bahasa penengah mampu membantu dalam komunikasi verbal. Akan tetapi, untuk komunikasi nonverbal perlu adanya saling keterbukaan dan pengertian dikarenakan adanya perbedaan latar belakang budaya.

Budaya organisasi merupakan falsafah yang dianut oleh organisasi atau perusahaan atau juga lembaga yang mengikat dan perlu diimplementasikan oleh semua karyawan, pegawai, pekerja dari sebuah organisasi. Dengan demikian menjadi ciri khas dari organisasi. John Van Maanen dan Stephen Barley menyampaikan dalam Littlejohn (2008) bahwa ada empat bidang dalam budaya organisasi seperti, konteks ekologis, interaksi diferensial, pemahaman kolektif, dan bidang individu. Konteks ekologis disebutkan contohnya adaah lokasi, waktu, sejarah, dan konteks sosial yang berkaitan dengan organisasi tersebut. Interaksi diferensial diterjemahkan sebagai jaringan dalam organisasi. Selanjutnya pemahaman kolektif merupakan kegiatan, citacita dan juga nilai yang terdapat dalam organisasi itu. Pada akhirnya bidang individu merupakan kegiatan individu di dalam organisasi.

Organisasi yang besar memiliki beberapa permasalahan terkait dengan keragaman budaya di dalamnya. Keragaman ini terjadi karena anggota yang berbeda latar belakang budaya berkumpul dan berkegiatan bersama dalam organisasi. Oleh karena itu, sebuah organisasi yang besar menciptakan budaya organisasi untuk kebersamaan. Kebersamaan mencapai tujuan organisasi sebagai bentuk bahasa yang sama guna individu yang bergabung di dalamnya.

Budaya organisasi dikatakan dalam Littlejohn bahwa dipengaruhi oleh tradisi sosiokultural dalam komunikasi. Gareth Morgan menjelaskan (Littlejohn, 2008) bahwa, pemaknaan bersama, pemahaman bersama dan perasaan bersama semuanya merupakan cara yang berbeda 
dalam menjelaskan budaya. Dalam membicarakan budaya, kita sebenarnya membicarakan sebuah proses pembentukan realitas yang memungkian manusia melihat dan memahami kejadian, tindakan, objek, ucapak, atau situasi tertentu dalam cara-cara yang berbeda. Polapola pemahaman ini juga memberikan sebuah dasar untuk membuat perilaku seseorang berarti dan pantas.

Dijelaskan lebih lanjut bahwa budaya organisasi tidak hanya terkait dengan pekerjaan seharihari dari interaksi para angggotanya, tetapi semua jenis komunikasi. Komunikasi seperti kegiatan, aktivitas, cerita, upacara dan ritual lain yang terjadi dalam organisasi. Pancanowsky dan O'Donnell Trujillo menyatakan dalam Littlejohn (2008) bahwa ada karakteristik penampilan dalam organisasi. Pertama adalah interaksional atau dialog. Penampilan ini merupakan tindakan sosial setiap anggotanya yang banyak dilakukan dan diikuti oleh anggotanya dalam organisasi. Kedua penampilan bersifat kontekstual. Penampilan ini yang ditampilkan oleh organisasi bukan sekedar tindakan, tapi merupakan cerminan dan hasil dari konteksnya. Ketiga penampilan adalah peristiwa. Peristiwa yang memiliki awal dan akhir.

Kategori penampilan dalam organisasi antara lain adalah ritual, hasrat, sosialitas, politik organisasi, dan enkulturasi (Littlejohn, 2008). Ritual ini merupakan kegiatan yang diulangi secara teratur (Littlejohn, 2008). Antara lain ritual pribadi, ritual tugas, ritual sosial, ritual organisasi

\section{Teori Pengelolaan Identitas}

Teori pengelolaan identitas yang akan digunakan adalah teori yang dikembangkan oleh Tadasu Todd Imahori dan William R. Cupach. Teori ini dijelaskan oleh LittleJohn \& Foss (2012) bahwa "bagaimana identitas terbentuk, terjaga, dan berubah dalam hubungan". Identitas seseorang yang berbeda menunjukkan adanya latar belakang budaya yang berbeda. Jika diperhatikan lebih teliti maka dalam hubungan ini terjadi komunikasi antar budaya. Adanya komunikasi antar pribadi yang berbeda budaya seperti contohnya komunikasi dengan keluarga atau rekan kerja. Imahori dan Cupach menyatakan bahwa ada tiga tahap dalam hubungan yang akan terjadi dalam bentuk penyesuaian identitas.

Tahap tersebut adalah percobaan, kecocokan, dan negosiasi ulang. Tahap percobaan atau trial menunjukkan adanya perbedaan budaya yang besar dan kerap muncul. Adanya tahap mencoba budaya yang berbeda, mencoba untuk menghindari adanya kebekuaan budaya serta menghindari munculnya tekanan dalam diri sendiri maupun orang lain yang berbeda budaya. Adanya sikap penyesuaian untuk berhasil dalam sebuah hubungan dan mencari pola yang sesuai dilakukan dalam tahapan ini. Selanjutnya muncul tahap kecocokan atau emmeshment. Pada tahapan ini mulai muncul kenyamanan satu sama lain, terdapat pembagian pemahaman budaya yang berbeda dalam interkasi interkultural yang terjalin satu sama lain. Tahapan ketiga adalah tahap negosiasi ulang atau negotiation. Adanya pengalaman perbedaan budaya melalui tahap-tahap sebelumnya menjadikan seorang dalam hubungan menjadi berkembang. Perbedaan budaya lebih mudah diatasi karena pengalaman yang telah dilalui. Tahap negosiasi dan percobaan telah dilewati dan bentuk kendala sebelumnya dapat dilalui ataupu dihindari dengan lebih baik. 


\section{METODE PENELITIAN}

Metode penelitian yang digunakan adalah kualitatif. Sarwono (2006) menyatakan bahwa "dalam penelitian kualitatif peneliti berbaur menjadi satu dengan yang diteliti sehingga peneliti dapat memahami persoalan dari sudut pandang yang diteliti itu sendiri" (p. 194). Demikian pula peneliti terlibat, mengalami, dan menjadi bagian dari objek penelitian. Fenomena yang terjadi di lingkungan pekerjaan penulis pada saat berada di lingkungan berbahasa Sunda. Adanya kendala dalam penggunaan bahasa dan juga nilai budaya dalam berinteraksi dengan lingkungan pekerjaan. Penelitian ini bersifat kini dan penting karena adanya permutasian dalam lingkungan pekerjaan dan adanya kemungkinan individu lain turut mengalami hal serupa. Oleh karena itu, penelitian ini menggunakan metode kualitatif karena peneliti tidak mengambil jarak dengan objek penelitian seperti disampaikan oleh Sarwono (2006) bahwa “...peneliti kualitatif tidak mengambil jarak dengan yang diteliti sebagaimana penelitian pendekatan kuantitatif yang membedakan antar peneliti sebagai subyek dan yang diteliti sebagi obyek” (p.194-195).

\section{HASIL DAN PEMBAHASAN}

\section{Bahasa Sunda}

Bahasa Sunda merupakan bahasa daerah yang digunakan oleh masyarakat yang tinggal di wilayah Jawa Barat. Bahasa Sunda merupakan bahasa ketiga yang paling banyak digunakan di Indonesia (Sukmawan, 2017). Pengguna bahasa Sunda menggunakan bahasa daerah ini dalam keseharian mereka. Demikian juga dalam lingkungan kerja peneliti yang dalam kesehariannya lebih sering menggunakan bahasa Sunda dalam berkomunikasi dengan sesama yang berasal dari Sunda ataupun orang non-Sunda yang mampu berbahasa Sunda.

Bahasa Sunda ini digunakan tidak hanya kepada rekan internal perusahaan tetapi juga digunakan pada saat bertemu dengan konsumen yang datang ke kantor. Penggunaan bahasa Sunda cukup kental didengarkan dalam percakapan keseharian di lingkungan kerja. Meskipun bahasa Indonesia digunakan pula sebagai bahasa lain untuk berkomunikasi dengan orang nonSunda atau orang yang tidak mengerti bahasa Sunda.

Peneliti mengalami dan melakukan observasi terhadap karyawan yang berkomunikasi di lingkungan kerja. Peneliti melihat dan mengalami kendala dalam berkomunikasi pada awal penempatan di lingkungan baru yang mayoritas karyawan adalah orang yang berbahasa Sunda. Adanya perbedaan bahasa yang dialami menimbulkan reaksi bingung terhadap peneliti. Perasaan sulit untuk memahami percakapan komunikasi antar karyawan dengan bahasa Sunda. Hal ini cukup membuat jarak antar peneliti dan karyawan lain. Meskipun ada bahasa Indonesia yang masih digunakan dalam interaksi dengan pegawai non-Sunda.

Hal ini diakui pula oleh karyawan yang bekerja di lingkungan berbahasa Sunda bahwa penggunaan bahasa daerah lebih sering digunakan untuk keseharian karena lebih akrab. 
Adapun selain observasi peneliti melakukan interview dengan dua orang yang memahami bahasa Sunda maupun dua orang lain yang tidak memahai bahasa Sunda.

Bahasa Sunda dan Budaya Sunda menjadi satu kesatuan yang saling berkaitan. Jika diperhatikan dalam kategori bahasa Sunda termasuk dalam high culture context. Adanya ungkapan yang dianut oleh masyarakat Sunda yaitu silih asih, silih asah, dan silih asuh. Semua orang Sunda harus saling asih, saling asah, dan saling asuh (Sumardjo, 2015). Sikap ini diperlukan supaya tanah Sunda menjadi aman, damai dan sejahtera.

Sumardjo (2015) menjelaskan lebih lanjut bahwa silih asih adalah tekad, silih asah adalah ucap dan silih asuh adalah lampah. Sedangkan silih asuh adalah pengamanan, penjagaan, saling menghidupi dan menghormati keberadaan yang berbeda. Tampak dengan adanya tingkatan dalam bahasa Sunda dan perbedaan penggunaanya. Melihat dari siapa yang diajak berbicara, secara kedudukan. Selanjutnya silih asah adalah pemikiran. Pikiran yang tajam, jernih yang dianut oleh budaya Sunda (Sumardjo, 2015). Jika diumpamakan melalui Sumardjo dalam pemerintahan sebagai contoh adalah kehendak atau tekad adalah DPRD, Pikiran atau Ucap adalah Gubernur sebagai pelaksana mandat keinginan DPRD, dan kekuatan atau tenaga adalah panglima.

\section{Karyawan Sunda}

Karyawan Sunda didefiniskan sebagai karyawan yang berasal dari Jawa Barat dan dapat berbahasa Sunda. RJ adalah seorang karyawan yang bekerja di lingkungan kerja peneliti di daerah Jawa Barat yang berasal dari Bandung. Usia karyawati tersebut adalah 31 tahun dengan masa kecil dan masa menempuh pendidikan hingga bekerja di Bandung. RJ belum pernah mengalami perbedaan budaya dengan berpindah ke daerah selain Bandung. Hal ini diperkuat pula dengan kemampuan RJ berbahasa daerah Sunda yang digunakan olehnya di rumah maupun di lingkungan kantor. RJ juga menyampaikan ketidakmampuannya mengerti bahasa daerah lain dengan alasan belum pernah merantau keluar daerah Jawa Barat.

RJ meyampaikan bahwa bahasa daerah Sunda yang digunakan sehari-hari membuatnya lebih akrab ketika berkomunikasi dengan rekan kerja. Akan tetapi ada perbedaan dalam hal penggunaan bahasa daerah tersebut bagi rekan kerja yang akrab dan bagi atasan. Penggunaan bahasa daerah Sunda yang halus digunakan RJ untuk orang yang lebih dihormati. Sekitar 40 orang yang bekerja di lingkungan tempatnya bekerja adalah orang yang dapat berkomunikasi dengan bahasa daerah Sunda. Adapun orang dari luar daerah yang bekerja di sana dan mengalami kesulitan dalam pemahaman bahasa daerah Sunda.

RJ menyampaikan bahwa akan membantu menjelaskan kesulitan orang yang tidak bisa berbahasa Sunda untuk memahami topik pembicaraaan yang dibahasa sebelumnya. Hal ini disampaikan oleh karyawati tersebut karena mayoritas karyawan di lingkungan kantor menggunakan bahasa daerah Sunda, sehingga penting bagi orang non-Sunda untuk turut mempelajari bahasa Sunda. Karyawati ini juga menyampaikan adanya perasaan lebih akrab dan mudah menyampaikan informasi dengan menggunakan bahasa daerah Sunda. 
Meskipun RJ belum pernah mengalami perpindahan lingkungan kerja maupun sekolah di luar Bandung, tetapi RJ menyampaikan jika berlibur ke daerah lain yang berbeda budaya maupun bahasa terdapat pula kesulitan. Pada saat berkunjung atau berlibur ke tempat lain karyawati tersebut merasakan kebingungan karena tidak memahami komunikasi bahasa daerah lain. Meskipun bingung RJ mencoba untuk bertanya dan mencari tahu mengenai arti dari bahasa daerah yang dimaksudkan dan hal ini dirasa sulit olehnya. Hal ini disebabkan karena mempelajari dan memahmi bahasa daerah itu butuh waktu yang tidak sebentar.

Karyawati ini menyampaikan pentingnya belajar bahasa daerah dan budaya lain untuk berkomunikasi. Menurutnya perlu mempelajari bahasa terlebih dahulu sebelum mendalami budaya lain. Selain bersedia berbagi mengenai bahasa daerah Sunda bagi orang yang tidak mengerti RJ juga membantu berbagi mengenai budaya Sunda yang sebaiknya diketahui. Contohnya bila masuk ke ruangan hendaklah mengucapkan salam. Selain itu apabila ada jamuan atau hidangan suatu acara sebaiknya tidak mendahului yang lebih tua. Selama masa kerja 3 (tiga) tahun 11 (sebelas) bulan di lingkungan tempatnya bekerja, karyawati ini pernah merasakan interaksi dengan atasan maupun rekan kerja yang berbeda budaya. RJ menyampaikan pengalaman pada saat ditanya mengenai perbedaaan atasan yang dapat berbahasa Sunda dengan yang tidak bisa. "Ya, atasan yang berbeda daerah cenderung susah beradaptasi dan berinteraksi karena cenderung kaku saat melakukan percakapan, apabila atasan yang satu daerah untuk melakukan interaksi ataupun intruksi lebih cepat tangkesenjangan dan cepat dipahami," disampaikan oleh RJ.

RJ menyampaikan mengenai pengalamannya berbagi dengan orang berbeda budaya misalkan di lingkungan tempat tinggalnya ketika ada tamu ataupun saudara yang berkunjung ke rumah. Saudaranya berasal dari Jawa Timur yang menggunakan bahasa Jawa Timur. RJ menawarkan saudaranya untuk mencicipi buah papaya, tetapi menggunakan bahasa Sunda "mangga gedangna di tampi". Reaksi yang didapatkan oleh RJ adalah saudaranya tertegun dan bingung karena yang ditawarkan adalah papaya bukan pisang, sedangkan dalam bahasa Jawa Timur gedang berarti pisang.

RJ turut membagi pengalaman ketika pergi makan ke rumah makan bersama teman dari daerah lain, Mataram. Temannya mencoba untuk berbaur dan belajar bahasa Sunda dengan meminta tolong padanya untuk mengajari bahasa Sunda. Teman dari Mataram ingin bertanya kepada petugas rumah makan dengan bahasa Sunda, bagaimana bahasa Sunda jika ingin berkata mau makan. RJ menyampaikan dalam bahasa Sunda "rek nyatu”. Teman dari Mataram langsung mempraktikkan penggunaan bahasa Sunda tersebut dan tidak mendapatkan respon karena marah. Hal ini membuat teman dari Mataram bingung. Melihat kebingungan temannya RJ kemudian menjelaskan bahwa nyatu dalam bahasa sunda bersifat kasar, biasanya digunakan untuk binatang. Jika ingin menggunakan bahasa halusnya adalah tuang atau dahar. Dalam hal pengalaman tersebut disampaikan bahwa budaya tidak hanya diwakili oleh bahasa semata, tetapi juga nilai dan norma yang mengikutinya. Apabila mempelajari bahasa maka perlu pula mempelajari budaya lain yang turut di dalamnya agar tidak terjadi kesalahpahaman dalam penggunaan bahasa. 
Selain RJ ada pula karyawan berbahasa Sunda lain yang bekerja di lingkungan kantor. DH berusia 48 tahun dan sudah bekerja selama 23 tahun di lingkungan berbahasa Sunda. Lahir dan besar di Bandung membuatnya menggunakan bahasa Sunda sebagai keseharian di rumah maupun di lingkungan kantor. Meskipun belum pernah merantau keluar Bandung, DH memahami bahasa daerah lain yaitu bahasa Jawa, tetapi tidak dapat menggunakannya. Menurut DH, bahasa Sunda memiliki tingkatannya masing-masing. Dijelaskan lebih rinci bahwa bahasa Sunda halus digunakan untuk orang yang usianya lebih tua dari kita, sedangkan untuk orang yang usianya setara atau sedikit lebih muda menggunakan bahasa Sunda yang menengah. Bahasa Sunda kasar digunakan untuk orang yang umurnya jauh lebih muda dari kita. Akan tetapi, bahasa kasar di tataran Sunda juga dapat menunjukkan seberapa dekat atau akrab kita dengan lawan bicara. Semakin kasar maka dianggap semakin akrab. Meskipun adanya tataran tingkat kehalusan dalam penggunaan bahasa Sunda menurut DH, bahasa Sunda yang digunakan di lingkungan kantor adalah bahasa Sunda halus, baik kepada atasan, rekan sejajar ataupun bawahan karena sebagai bentuk saling menghormati satu sama lain.

Hampir 90\% karyawan di lingkungannya bekerja adalah orang bersuku Sunda. Akan tetapi, DH menempatkan diri secara berbeda untuk pokok pembicaraan yang akan dibahas. Misalkan jika pembicaraan seputar pekerjaan, tanggungjawab biasanya menggunakan bahasa Indonesia. Sementara untuk komunikasi sehari- hari yang bersifat interakasi sosial serta tidak formal digunakan bahasa daerah Sunda. Selain dengan rekan kerja secara internal, penggunaan bahasa daerah Sunda juga digunakan untuk konsumen. Akan tetapi, bergantung pula dari suku konsumen itu sendiri, atauapun kebiasaan dari konsumen. Konsumen bersuku Sunda pun ada yang datang dan berkomunikasi menggunakan bahasa Indonesia. Ada pula konsumen Sunda yang juga menggunakan bahasa Sunda.

Saat ini pimpinan di tempatnya bekerja pun berasal dari suku yang berbeda. Adanya kendala bahasa dan ketidakpahaman dari pimpinan non-Sunda pun muncul, maka DH berkomunikasi dengan bahasa Indonesia. Akan tetapi bila lawan bicara tidak paham bahasa Sunda untuk menghindari kesalahpahman maka sebaiknya digunakan bahasa Indonesia. Meskipun demikian bagi DH perlu adanya orang luar daera Sunda untuk memahami dan mengerti bahasa Sunda. Adapun menurut DH adalah agar maksud dan tujuan berkomunikasi dapat tercapai ataupun saling memahami. Kemudian tidak menjadi kendala negatif akibat kesalah pahaman sehingga tujuan komunikasi tidak tercapai. Ditambahkan pula dengan mempelajari bahasa daerah dapat menciptakan hubungan harmonis di lingkungan kerja.

Meskipun belum pernah merantau dan mengalami culture shock akibat perbedaan bahasa, tetapi pengalaman kebingungan saat mendengar orang menggunakan bahasa daerah lain pun pernah dialami. DH tidak sampai dengan perasaan tersinggung karena tidak paham, melainkan tidak merespon. Akan tetapi, jika paham maka akan muncul respon, baik itu negatif ataupun positif.

DH pun menyampaikan bahwa perlu dan penting untuk belajar bahasa daerah di mana kita berada. Akan tetapi harus belajar dari orang yang bertanggunjawab. Maksudnya agar diajarkan secara benar, bukannya dengan dipermainkan. Selain bahasa DH menyampaikan bahwa norma 
dan nilai budaya perlu juga dipahami karena di mana bumi dipijak disitu langit dijunjung. Tidak bisa hanya belajar bahasa saja karena bahasa dan budaya merupakan satu kesatuan.

DH turut memberikan contoh budaya yang perlu dipahami oleh orang luar Sunda, yaitu selalu berusaha saling menghormati, seperti saat datang dengan menyapa selamat pagi atau selamat siang, dan saat pulang berpamitan. Selain itu, bisa memahami tim yang ada di lingkungan kerja. Dengan adanya pemahaman yang baik akan mudah melakukan koordinasi dengan team tanpa mengorbankan kepentingan perusahaan dan atasan. Kemudian perlu juga memahai budaya yang sudah dijalani dan melakukan perbaikan jika ada orang yang salah memahaminya.

\section{Karyawan Non-Sunda}

D adalah karyawan perempuan yang lahir di Jakarta dan sudah 8 tahun bekerja di perusahaan ini. D menggunakan bahasa Indonesia dan bahasa Padang sebagai bahasa sehari-hari. D juga pernah mengalami perpindahan tugas kerja di luar Bandung, yaitu Lampung. D menyampaikan bahasa yang digunakan di lingkungan kerjanya merupakan kombinasi, baik bahasa daerah Sunda maupun bahasa Indonesia. D menyampaikan kemampuannya berbahasa daerah sekedar mengerti saja. Oleh sebab itu, D lebih memilih menggunakan bahasa Indonesia sebagai bahasa sehari-hari di kantor.

D merasa bahwa bahasa daerah sebaiknya dipelajari karena dengan menggunakan bahasa daerah rasa akrab terjalin. Selain bahasa budaya lain termasuk nilai dan norma perlu dipelajari juga sebagai satu kesatuan. Pengalaman D dalam mutasi pekerjaan di luar tempat lahirnya memberikan bekal pengalaman dan penyesuaian ketika masuk ke daerah lain yang berbeda budaya. Demikian juga menghadapi bahas daerah Sunda yang saat ini dirasakan di lingkungan pekerjaannya. D menyampaikan tidak ada kesulitan yang menjadi hambatan dalam pekerjaannya.

Ada pula IW. karyawan pria yang lahir dan besar di Semarang. Bahasa keseharian yang digunakan di rumah oleh IW adalah bahasa Indonesia dan Jawa. Bahasa yang digunakan di kantor juga merupakan kombinasi bahasa Sunda dan bahasa Indonesia. IW pernah mengalami mutasi pekerjaan dengan daerah yang masih seputar Jawa Barat, sehingga IW menjadi paham bahasa Sunda. Akan tetapi, pilihan menggunakan bahasa Indonesia menjadi yang utama untuk kemudahan berkomunikasi. Meskipun disampaikan pula dengan menggunakan bahasa daerah ada perasaan lebih akrab.

Pada mulanya IW juga merasakan kesulitan dan bingung serta perasaan curiga saat tidak paham bahasa Sunda. Hal ini membuat IW harus mencari cara untuk belajar, salah satunya adalah mengajak rekan kerja untuk makan bersama atau bermain atau karaoke. Agar kekaraban dapat lebih terjalin dan lebih luwes. Selain itu, IW juga mencari 1 orang yang mampu dipercaya untuk membantunya mengajari bahasa daerah Sunda.

\section{Komunikasi Beda Bahasa}

Komunikasi adalah proses di mana informasi atau pesan disampaikan dari komunikator ke komunikan. Komunikasi dikatakan berhasil ketika adanya respon dari penerima pesan atau 
adanya feedback. Demikian juga dengan komunikasi dalam lingkungan kerja di perusahaan ini. Adanya interaksi antara IW saat berbagi pengalaman pertama kali bekerja di Jakarta. IW memiliki aksen bahasa Jawa yang cukup kental atau yang biasa disebut medok. Pertama kali bekerja di Jakarta dan mencoba mengikuti bahasa gaul Jakarta, seperti penyebutan saya yang adalah gue dan kamu adalah lo terasa canggung untuknya. Bukan hanya untuk IW tapi juga untuk orang Jakarta yang mendengarkannya. Melalui komunikasi ini dapat terlihat identitas dari IW yaitu berasal dari Jawa.

Perbedaan bahasa Jakarta dan bahasa Jawa tidak terlalu signifikan karena masih menggunakan bahasa Indonesia tetapi aksennya berbeda ataupun bahasa slang-nya berbeda. Kesulitan mulai dirasakan IW ketika pekerjaannya mutasi ke Sukabumi. Sukabumi adalah salah satu daerah di Jawa Barat yang menggunakan bahasa Sunda sebagai bahasa daerah. IW menyampaikan bahwa karyawan di lingkungan kantornya menggunakan bahasa Sunda. Hal ini membuat IW merasakan adanya perasaan negatif dan takut jika ada yang membohonginya. Ada perasaan orang akan berbuat nakal seperti korupsi ataupun ada hal yang ditutupi saat berkomunikasi dengan bahasa Sunda.

\section{Tahap Percobaan}

Dalam hasil interview dengan pekerja Sunda dan non-Sunda dengan adanya kendala perbedaan bahasa dialami pula tahap percobaan. Dengan mempelajari maupun mengajari orang berbeda budaya dengan bahasa daerah Sunda menjadi satu tahap percobaan. Hal ini menunjukkan tahapan apakah ada kecocokan atau tidak. Tahap percobaan ini masing-masing di lalui oleh karyawan yang di-interview. Hal ini dilakukan ditahapan awal untuk menyesuaian budaya mereka dengan budaya lain.

Tahap percobaan ini juga digambarkan oleh narasumber RJ dengan berbagi pengalaman melalui kawannya yang adalah orang Mataram. Dalam penggambaran RJ, orang Mataram ini melewati tahap percobaan. Orang Mataram ini meminta RJ untuk membantunya menggunakan bahasa Sunda, dan bertanya mengenai ajakan makan bahasa Sunda, yang kemudian dibantu oleh RJ. Akan tetapi, RJ menyampaikan dengan menggunakan bahasa Sunda kasar. Sehingga reaksi lawan bicara yang mendengarkan kawan RJ bertanya menjadi marah. Bahasa "nyatu" atau makan dalam bahasa Indonesia bersifat kasar, bisa digunakan juga untuk binatang. Sebaiknya menggunakan bahasa halus yaitu "tuang" atau "dahar". Hal ini menunjukkan adanya tahap percobaan dari kawan RJ untuk menyesuaikan diri.

\section{Tahap Kecocokan}

Tahapan berikut ini pun dilalui oleh para karyawan dalam pemahaman budaya di lingkungan pekerjaan Sunda. Hal ini dilihat dari adanya pemahaman bagi karyawa non-Sunda terhadap bahasa Sunda, demikian juga karyawan Sunda menggunakan bahasa Indonesia. Hal ini adalah bukti perlunya penyesuaian antar beda budaya agar tidak berbenturan. Tahap ini merupakan tahap lanjutan dari tahap percobaan. Setelah melalui percobaan, maka bekal pengalaman untuk belajar hal baru muncul. Seperti contoh, kejadian pada kawan RJ sebelumnya, yaitu DH yang menyampaikan informasi serupa bahwa tahap kecocokan ini terjadi saat kita belajar dari orang yang bertanggungjawab memberikan pelajaran. DH mengetahui bahwa ada kemungkinan pada 
saat belajar akan muncul ketakutan karena dipermainkan atau bahkan semangat untuk belajar lagi.

Seperti hubungan antar individu yang berbenturan bahasa ini, tahap kecocokan mulai muncul ketika sudah ada kepercayaan dan saling menghormati. Hal ini ditunjukkan dengan saling bertukar budaya. Mulai beradaptasi terhadap lingkungan baru dan juga bahasa serta

\section{Tahap Negosiasi Ulang}

Tahapan negosiasi ulang ini dijalani oleh karyawan dengan budaya yang berbeda pula untuk mendapatkan formula yang tepat dalam berinteraksi. Tidak adanya halangan ataupun kendala yang besar dalam berkomunikasi meskipun berbeda bahasa dan budaya yang dihadapi. Tahap negosiasi ulang ini muncul sebagai tahap akhir menerima budaya lain. Sebagai contoh di lingkungan kerja adalah tempat memulai lancarnya berkomunikasi. IW menyampaikan bahwa dalam bahasa Jawa adanya tatanan bahasa kasar, sedang, dan juga halus. DH pun menyampaikan hal serupa bahwa dalam bahasa Sunda pun terdapat bahasa yang disesuaikan dengan lawan bicara. Hal ini menunjukkan adanya kemiripan dalam bahasa dan budaya Jawa dan Sunda. Hal ini memunculkan tahap saling menghormati karena sudah mengenal dan memahami budaya yang berbeda. Munculnya pula bahasa Sunda dengan aksen Jawa. Ataupun sebaliknya bahasa Jawa beraksen Sunda.

\section{Budaya Organisasi}

Budaya organisasi dipengaruhi oleh komunikasi. Gareth Morgan dalam Littlejohn (2008) menjelaskan "pemaknaan bersama, pemahaman bersama, dan perasaan bersama semuanya merupakan cara yang berbeda dalam menjelaskan budaya. Dalam membicarakan budaya, kita sebenarnya membicarakan sebuah proses pembentukan realitas yang memungkinkan manusia melihat dan memahami kejadian, tindakan, objek, ucapan, atau situasai tertentu dalam caracara yang berbeda. Pola-pola pemahaman ini juga memberikan sebuah dasar untuk membuat perilaku seseorang berarti dan pantas".

Budaya organisasi dalam perusahan "XXX" ini terbentuk dari proses komunikasi keseharian dari para karyawannya. Perusahaan ini menyadari bahwa sebagai perusahaan yang memiliki kantor cabang tersebar di Indonesia pasti memiliki anggota atau karyawan yang beragam. Keberagaman ini tentu termasuk di dalamnya perbedaan budaya. Adanya konflik dan hambatan dalam komunikasi kerap terjadi. Adanya aturan yang diterapkan pada satu kantor cabang belum tentu dapat menjadi aturan yang bermanfaat bagi cabang lain. Dengan adanya permutasian antar karyawan dari setiap wilayahnya memberikan pengalaman baru bagi organisasi. Memberikan pengalaman baru untuk membuat aturan, kegiatan, dan juga dasar lain guna kemajuan perusahaan.

Perusahaan pembiayan non-bank ini memiliki 73 kantor cabang yang tersebar di seluruh Indonesia yang menyebabkan adanya permutasian dan perubahan dalam pekerjaan. Perubahan dalam organisasi yang dinamis membuat banyaknya pertukaran informasi dan budaya secara tidak disadari. Pertukaran budaya ini melalui tahapan-tahapan yang menjadikan pengalaman bagi organisasi untuk berkembang. 
Perusahaan memberikan pelatihan kepada karyawan dengan melalui pembekalan ilmu sesuai dengan jabatannya. Selain pembekalan ilmu perusahaan ini juga menjalankan budaya organisasi yang baik, yaitu dengan menerapkan visi dan misi serta nilai perusahaan secara formal maupun non formal. Kesamaan tujuan dari setiap karyawan mampu menjadi alat komunikasi untuk mencapai target bersama. Selain itu terdapat nilai-nilai perusahaan yang menjadikan perusahaan memiliki identitas yang kuat, yang perlu untuk dipahami oleh para karyawan. Adapun 4 nilai perusahaan adalah integrity, teamwork, quality, dan juga customer satisfaction.

Melalui uraian penjelasan tersebut dapat dilihat bahwa adanya ritual yang terjadi dalam organisasi, membentuk adanya kesatuan bahasa yang digunakan setiap hari. Ritual yang merupakan kebiasaan yang dijalankan dalam perusahaan menjadi penting dalam budaya organisasi. Dalam organisasi ini adanya Ritual pribadi yang dijalankan oleh masing-masing fungsi. Ritual pribadi, misalkan atasan melakukan penarikan data pencapaian karyawan pada hari sebelumnya untuk dipersiapakan sebagai bahan briefing pagi bersama. Seorang pimpinan mempelajari hasil pencapain lebih dulu secara pribadi dan kemudian membahasnya bersama team. Adanya aturan ini memberikan kesempatan bagi atasan untuk berinteraksi dengan karyawan, sebagai salah satu sarana berkomunikasi.

Ritual berikutnya yang juga ada dalam perusahaan adalah Ritual tugas. Ada SOP atau standart operasional prosedur perusahaan yang mesti dijalankan oleh karyawan dalam bertugas. Contohnya, ritual bagi karyawan teller yang wajib menyapa customer yang datang. Menyapa dengan senyum dan kemudian menanyakan keperluan customer. Apabila ingin membayar meminta data customer. Selanjutnya teller wajib menghitung uang yang diterima dari customer di depannya. Menyebutkan nominal uang yang diterima dan memberikan tanda bukti serta uang kembalian, jika ada. Tidak lupa menyapa kembali dengan senyum dengan ucapan terima kasih. Ritual ini dilakukan berulang kali sebagai bentuk komunikasi pelayanan kepada masyarakat. Adapun ritual ini menggunakan bahasa Indonesia.

Ritual sosial juga difasilitasi oleh perusahaan ini. Bukan hanya acara makan bersama yang diadakan secara individu atau inisiatif dari atasan atau salah satu karyawan tetapi difasilitasi oleh perusahaan. Perusahaan memberikan alokasi dana setahun kepada cabang sebagai bentuk dukungan untuk kegiatan kebersamaan. Kegiatan wajib didokumentasikan dan dirinci biayanya. Kegiatan dapat berupa makan bersama, menonton bioskop bersama, ataupun olahraga bersama seperti futsal atau senam. Kegiatan-kegiatan ini dijalankan untuk membangun keakraban antar karyawan. Adanya tugas dan pekerjaan yang cukup padat bagi setiap karyawan memberikan rasa jenuh dan juga minimnya komunikasi informal. Oleh karena itu organisasi memberikan kesempatan dan sarana bagi karyawan untuk saling mengenal dan berinteraksi lebih intens dalam aktivitas di luar jam kerja.

Ritual lain adalah Ritual organisasi yang diadakan atau difasilitasi oleh perusahaan ini. Bentuk ritual ini sebagai contoh adalah adanya rapat tahunan bagi para pejabat cabang di satu tempat. Kegiatan ini guna mengumpulkan setiap pejabat untuk mendapatkan informasi. Untuk dapat 
berkomunikasi saling tukar pengalaman dan juga pencapaian selama setahun. Selain acara tahunan ada pula acara midyear. Setengah tahun setelah pencapaian, organisasi mengadakan event untuk dijalankan oleh setiap pejabat dengan berkumpul bersama di satu tempat. Informasi yang ingin disampaikan dapat diberikan sarana.

\section{SIMPULAN}

Perbedaan bahasa Sunda tidak menjadi halangan yang berarti bagi karyawan non-Sunda, dikarenakan adanya interaksi dan berkomunikasi dengan menggunakan bahasa Indonesia yang dipahami semua pihak. Adapun solusi untuk mengatasi perbedaan budaya tersebut adalah dengan mendekatkan diri dan dengan berinterkasi di luar jam kerja. Terutama pada saat makan bersama, ataupun aktivitas karaoke bersama. Hal ini secara bertahap dapat menjalin keakraban dan juga membangun komunikasi yang efektif di antara para karyawan.

Adanya adaptasi dengan melalui tahap pengenalan identitas yang berbeda budaya juga penting adanya. Tahapan tersebut dapat dilalui dengan baik oleh para subjek penelitian. Baik tahap percobaan, kecocokan dan negosiasi ulang. Pada awalnya, orang non Sunda mengalami hambatan dari segi bahasa dan budaya. Namun, dengan menjalani tahapan adaptasi, pada akhirnya diperoleh solusi untuk dapat berkomunikasi. Selain itu, bahasa Indonesia membantu sebagai bahasa pemersatu dalam berkomunikasi secara formal.

Perbedaan bahasa tidak menjadi permasalahan pelik dalam lingkungan kerja ini, karena adanya bahasa Indonesia yang digunakan sebagai bahasa resmi. Secara individu masing-masing karyawan telah memiliki kemampuan adaptasi dan juga kemampuan menyesuaian diri.

Sebagai saran, (1) Penelitian lain dapat dilakukan dengan lebih detail dengan lebih berfokus pada dua suku yang berbeda agar dapat dilihat hasil yang lebih signifikan; (2) Penelitian perlu lebih detail membahasa bahasa Sunda atau budaya apa yang menjadi kendala dalam berkomunikasi; (3) Untuk penelitian lain adalah perlu adanya pembekalan budaya sebelum karyawan diberangkatkan mutasi tidak hanya sekedar kondisi pencapaian cabang untuk target performance tetapi juga bahasa dan budaya. 


\section{DAFTAR PUSTAKA}

Ariyani, N. I. (2013). Strategi, Adaptasi Orang Minang terhadap Bahasa, Makanan, dan Norma Masyarakat Jawa. Komunitas: International Journal of Indonesian Society and Culture, 5(1), 26-37. https://doi.org/10.15294/komunitas.v5i1.2369

Armansyah, W. (2015). Penyebab Terjadinya Perbedaan Bahasa Setiap. BelajarBagus.net. http://www.belajarbagus.net/2015/08/penyebab-terjadinya-perbedaan-bahasa-setiapsuku-bangsa.html

Billore, G., \& Borg, J. E. (2014). Cultural Entry Barriers for SMEs : An Exploratory Study of Cultural Entry Barriers for foreign SMEs entering Japan (No. Publikasi 724504) [Tesis Magister, Linnæus University]. Digitala Vetenskapliga Arkivet.

Chaer, A. (2007). Kajian Bahasa: Struktur Internal, Pemakaian, dan Pemelajaran. Rineka Cipta.

Chrysha, M. (2016, Mei 13). Berapa Banyak Pulau di Indonesia?. Kompas. http://edukasi.kompas.com/read/2016/05/13/17374591/berapa.banyak.pulau.di.indone sia

Hardjana, A. M. (2003). Komunikasi Intrapersonal dan Interpersonal. Kanisius.

Heryadi, H., \& Silvana, H. (2013). Komunikasi Antarbudaya dalam Masyarakat Multikultur (Studi tentang Adaptasi Masyarakat Migran Sunda di Desa Imigrasi Permu Kecamatan Kepahiang Provinsi Bengkulu). Jurnal Kajian Komunikasi, 1(1), 95-108. https://doi.org/10.24198/jkk.v1i1.6034

Liliweri, A. (2002). Makna Budaya dalam Komunikasi Antarbudaya. LKIS Yogyakarta.

Liliweri, A. (2013). Dasar-dasar Komunikasi Antarbudaya. Pustaka Pelajar.

Littlejohn, S. W., \& Foss, K. A. (2015). Teori Komunikasi Theories of Human Communication (9th ed.). Salemba Humanika.

Mulyana, D., \& Rakhmat, J. (Eds.). (2005). Komunikasi Antarbudaya Panduan Berkomunikasi dengan Orang-Orang Berbeda Budaya. Remaja Rosdakarya.

Musfar, T. F., \& Novia, V. (2012). Pengaruh Experiental Marketing terhadap Customer Loyalty pada Pelanggan Restoran Koki Sunda di Pekanbaru. Jurnal Ekonomi, 20(4).

Na'im, A., \& Syaputra, H. (2012). Kewarganegaraan,Suku Bangsa, Agama, dan Bahasa Sehari-hari Penduduk Indonesia: Hasil Sensus Penduduk 2010. Badan Pusat Statistik. 
Novianti, E. (2014). Pola Komunikasi Pasangan Antaretnik Sunda-Minang di Bandung (Studi Etnografi Komunikasi Pasangan Sunda-Minang perantauan dalam pembentukan etnik di Pasar Baru Trade Center). Jurnal Kajian Komunikasi, 2(2), 161-172. https://doi.org/10.24198/jkk.v2i2.7383

Nugroho, A. B., Lestari, P., \& Wiendijarti, I. (2012). Pola Komunikasi Antarbudaya Batak dan Jawa di Yogyakarta. Jurnal ASPIKOM, 1(5), 403-418. http://dx.doi.org/10.24329/aspikom.v1i5.44

Nuryanto. (2011). Ilmu Komunikasi dalam Konstruksi Pemikiran Wilbur Schramm. Jurnal Komunikasi Massa, 4(2), 1-16.

Ridwan, A. (2016). Komunikasi Antarbudaya Mengubah Persepsi dan Sikap dalam Meningkatkan Kreativitas Manusia. CV Pustaka Setia.

Rozalena, A. (2014). Model Budaya Organisasi Berbasis High and Low Context Pada Kegiatan Komunikasi Bisnis Antarbudaya. Proseding Seminar Bisnis \& Teknologi, 2407-6171.

Samovar, L. A., Porter, R. E., \& McDaniel, E. R. (2010). Komunikasi Lintas Budaya Communication Between Cultures (7th ed.). Salemba Humanika.

Setiawati, I. (2008). Peran Komunikasi Massal dalam Perubahan Budaya dan Prilaku Masyarakat. Jurnal Fokus Ekonomi, 3(2), 44 - 55.

Sumardjo, J. (2015). Sunda Pola Rasionalitas Budaya. Kelir.

Tedjakusuma, F., \& Sutanto, E. M. (2015). Komunikasi Antar Karyawan Etnis Jawa dan Tionghoa. Jurnal Manajemen dan Kewirausahaan, 17(2), 167-176. https://doi.org/10.9744/jmk.17.2.177-186

Teguh, M. (2017). Komunikasi Lintas Budaya antara Dosen dan Mahasiswa Asing Asal Korea di Universitas Ciputra. Jurnal Visi Komunikasi, 14(2), 157-168.

Utami, Y. S. (2016). Pola Komunikasi Etnis Arab dan Etnis Sunda dalam Perkawinan Mut'ah di Kecamatan Pacet Kabupaten Cianjur. Jurnal Kajian Komunikasi, 4(1), 75-83. https://doi.org/10.24198/jkk.vol4n1.7

West, R., \& Turner, L.H. (2008). Pengantar Teori Komunikasi: Analisis dan Aplikasi (3rd ed.). Salemba Humanika.

Wiryanto. (2004). Pengantar Ilmu Komunikasi. Grasindo. 
Zahra, A. A., \& Prasetya, A. (2016). Pengaruh Cultural Barrier terhadap Komunikasi Lintas Budaya dan Stress Kerja Karyawan (Studi pada Karyawan PT. Krakatau Daedong Machinery - Cilegon. Jurnal Administrasi Bisnis (JAB), 36(1), 82-91. 